\title{
Az epilepsziasebészet eredményességének változása 2006 és 2016 között az Országos Klinikai Idegtudományi Intézetben
}

\author{
Jordán Zsófia dr.*1 - Horváth Boglárka dr. ${ }^{* 1}$ - Hajnal Boglárka dr. ${ }^{1}$ \\ Halász László dr. ${ }^{2}$ - Ujvári Ákos dr. ${ }^{1}$ - Fogarasi András dr. ${ }^{3}$ \\ Halász Péter dr. ${ }^{1}$ - Kelemen Anna dr. ${ }^{1}$ - Erőss Loránd dr. $^{2}$ - Fabó Dániel dr. ${ }^{1}$ \\ ${ }^{1}$ Országos Klinikai Idegtudományi Intézet, Neurológia Osztály, Epilepszia Centrum, Budapest \\ ${ }^{2}$ Országos Klinikai Idegtudományi Intézet, Funkcionális Idegsebészeti Osztály, Budapest \\ ${ }^{3}$ Bethesda Gyermekkórház, Neurológiai Osztály, Budapest
}

Bevezetés és célkitüzés: A terápiarezisztens fokális epilepsziák sebészeti kezelése elterjedten használt kezelési lehetőség. Célunk az epilepsziasebészet-hatékonyság változásának vizsgálata egy évtizednyi távlatból a budapesti centrumban. Módszerek: Az Országos Klinikai Idegtudományi Intézetben reszektív epilepsziasebészeti beavatkozásokon átesett fokális epilepsziás betegek adatai kerültek feldolgozásra. A vizsgált 10 év beteganyagát két periódusra osztottuk a mútét időpontja szerint (2006-2010 és 2011-2016). Vizsgálati szempontjaink: demográfiai adatok, az epilepszia kezdete és típusa, mágnesesrezonancia-lelet, preoperatív rohamfrekvencia, mútéttípus és szövettani lelet. Az epileptológiai kimenetelt az Engel-klasszifikáció alapján értékeltük.

Eredmények: Epilepsziasebészeti beavatkozás 187 betegen történt, akik közül 137-nél került sor reszekciós mútétre. A betegek 65\%-ában temporalis, 18\%-ában frontalis, míg 7\%-ában olyan multilobaris epilepszia igazolódott, mely a temporalis vagy a frontalis lebenyt érintette. Teljes rohammentességet (Engel I/A) az l. évben 68\%-ban, a 2. évben 64\%-ban, míg az 5. évben 63\%-ban mértünk. A két intervallum összehasonlításakor az 1 éves rohammentesség aránya 60\%-ról (temporalis: 67\%, extratemporalis: 50\%) 73\%-ra (temporalis: 79\%, extratemporalis: 62\%) javult a második periódusban. Az etiológia szempontjából a hippocampalis sclerosis aránya 28\%-ról 14\%-ra csökkent, a fokális corticalis dysplasiák aránya 22\%-ról 31\%-ra növekedett.

Következtetés: A sebészeti kezelés fokális epilepsziák esetén - alapos előzetes kivizsgálást követően - általában biztonságos és a legnagyobb arányban sikeres beavatkozás. A legkedvezőbb kimenetel temporalis lokalizációban érhető el. A hatékonyság az évek során egyre javuló tendenciát mutatott az egyre nehezebb sebészeti esetek ellenére. Ez magyarázható a sebészeti technikák fejlődésével, illetve a jobb, mútét előtti elektrofiziológiai és képalkotó technikákkal, amelyek bevezetésével pontosabb lokalizáció adható.

Orv Hetil. 2021; 162(6): 219-226.

Kulcsszavak: fokális epilepszia, epilepsziasebészet, mútéti kimenetel

\section{Changes of the outcomes of epilepsy surgery within 10 years in the National Institute of Clinical Neurosciences, Hungary}

Introduction and objective: The surgical treatment of medically intractable focal epilepsies is a well established practice. Our aim was to examine the efficacy of epilepsy surgery within a decade long period in our centre in Budapest. Methods: Data of drug-resistant patients with resective epilepsy surgery in the National Institute of Clinical Neurosciences were evaluated. The examined 10-year period was divided based on the year of the operation in two parts (2006-2010 and 2011-2016). The following data were collected: demography, beginning and type of epilepsy, magnetic resonance, preoperative seizure frequency, type of surgery and histology. Epileptological outcome was based on modified Engel's classification.

*Megosztott első szerzők, egyenlő mértékben járultak hozzá a cikk elkészítéséhez. 
Results: Out of 187 surgeries, we identified 137 patients with resective intervention: 65\% temporal lobe, $18 \%$ frontal, and $7 \%$ multilobar epilepsy. Seizure-freedom (Engel I/A) was $68 \%$ in the first postoperative year, $64 \%$ in the second, and $63 \%$ in the fifth year. In the first period, 1 -year seizure freedom was $60 \%$ (temporal: $67 \%$ extratemporal: $50 \%$ ), while in the second period it was $73 \%$ (temporal $79 \%$, extratemporal $62 \%$ ). Hippocampal sclerosis ratio dropped from $28 \%$ to $14 \%$, while focal cortical dysplasia ratio increased from $22 \%$ to $31 \%$.

Conclusion: Surgical treatment in focal epilepsy - after thorough presurgical evaluation - is generally safe and successful. The most favorable outcome is in temporal localization. The efficacy tended to improve over time despite of the more challenging cases. This can be explained with the development of surgical techniques and improvement of presurgical localization.

Keywords: focal epilepsy, epilepsy surgery, surgical outcome

Jordán Zs, Horváth B, Hajnal B, Halász L, Ujvári Á, Fogarasi A, Halász P, Kelemen A, Erôss L, Fabó D. [Changes of the outcomes of epilepsy surgery within 10 years in the National Institute of Clinical Neurosciences, Hungary]. Orv Hetil. 2021; 162(6): 219-226.

(Beérkezett: 2020. július 17.; elfogadva: 2020. augusztus 23.)

\section{Rövidítések}

$\mathrm{EEG}=$ elektroencefalográfia $; \mathrm{FCD}$ = fokális corticalis dysplasia; HS = hippocampalis sclerosis; IKEB = Intézményi Kutatásetikai Bizottság; ILAE = (International League Against Epilepsy) Nemzetközi Epilepsziaellenes Liga; MRI = (magnetic resonance imaging) mágnesesrezonancia-képalkotás; $\mathrm{PET}=$ (positron-emission tomography) pozitronemissziós tomográfia; SUDEP $=($ sudden unexpected death in epilepsy $)$ hirtelen halál epilepszia következtében; TLE = temporalislebeny-epilepszia

Az epilepszia az egyik leggyakoribb krónikus neurológiai betegség, mely az életminőség csökkenését okozhatja [1]. Az epilepszia mortalitási rátája két-háromszor nagyobb az egészséges populációhoz viszonyítva $[2,3]$. A magasabb morbiditás és mortalitás hátterében különböző tényezők fedezhetők fel, melyek a tartósan fennálló rohamokkal állnak összefüggésben: sérülések roham közben, status epilepticus, kognitív hanyatlás, pszichopatológiai tünetek (depresszió és pszichózis, öngyilkossági hajlam) és SUDEP (sudden unexpected death in epilepsy - hirtelen halál epilepszia következtében) [4]. A terápia célja a rohammentesség elérése.

Hozzávetőlegesen körülbelül a betegek 30\%-a gyógyszerrezisztens [5]. Az ILAE ajánlása szerint terápiarezisztencia áll fenn, ha két, megfelelően kiválasztott és jól tolerált antiepileptikum-rezsim (lehet monoterápia vagy kombináció) ellenére sem érhető el rohammentesség [6]. Epilepsziasebészeti mútét gyógyszerrezisztens fokális epilepsziás betegek részére javasolható. A sebészeti beavatkozás célja az epilepsziás góc eltávolítása neurológiai károsodás nélkül $[7,8]$.

Tekintve, hogy a rohamok epilepsziásan átalakult kérgi területekből indulnak ki, az epilepsziasebészeti mútétek az etiológiát jelentő laesio - például daganat, érmalformatio stb. - kimetszése mellett jellemzően kérgi területek reszekcióját jelenti. Az eltávolítandó terület lehet egyénre szabott vagy standard. Ez utóbbiak közé tartoz- nak a részleges vagy teljes lebenyreszekciók, amelyeket temporalislebeny-epilepszia (TLE) esetében alkalmaznak a leggyakrabban. A kiterjesztettebb mútét, az elülső temporalis lobectomia során a teljes pólus és a mesialis területek nagy része mellett a basalis és lateralis területek elülső részei is eltávolításra kerülnek. A redukált változat, az amygdalohippocampectomia során csak a hippocampus/entorhinalis kéreg, illetve a temporalis kamraszarv előtt elhelyezkedő, az amygdalát is magában foglaló poláris terület kerül eltávolításra.

Az egyénre szabott kérgi mútéteket összefoglalóan cortectomiának nevezzük, amikor a mútét előtti elektrofiziológiai és képalkotó módszerekkel meghatározott neocorticalis fókuszt célzottan távolítják el mikrosebészi eljárással. A mútét során a reszekálandó felszín corticographiás ellenőrzése és ingerlése segíthet a fókusz területének pontosabb meghatározásában.

A reszekciók mellett diszkonnekciós mútéttípusok is alkalmazhatók, amikor kérgi terület nem kerül eltávolításra, csak a rövid és hosszú kapcsolataikat szakítják meg. Ilyen a callosotomia, amely a corpus callosum első kétharmadának átmetszését jelenti; ez elsősorban a tónusos axiális rohamok kezelésében használatos eljárás. A gyermekkori, teljes féltekét érintő katasztrófaepilepsziák - például Rasmussen-encephalitis - során alkalmazott hemispherectomia mútétek is inkább a diszkonnekciós csoportba tartoznak manapság: a hemispherotomia során a félteke nem kerül eltávolításra, csak diencephalicus, agytörzsi és ellenoldali kapcsolatainak átvágása történik meg.

Mútét után a rohammentesség aránya 38-85\%-os, az etiológiától függően [9-12]. A temporalis epilepszia a leggyakrabban operált epilepsziaszindróma; a mútét hatékonysága 58\%-ra tehetô randomizált vizsgálatban és $73-85 \%$ egyéb tanulmányokban $[9,10]$. A mi vizsgálatunkhoz hasonló magyar vizsgálatban 72 , mútéten átesett beteg közül $76 \%$ volt rohammentes a mútét után 
[13]. Az MRI-negatív, nem laesiós esetek nagyobb kihívást jelentenek: a rohammentesség 38\%-ra csökkent randomizált vizsgálatban, illetve 54-59\%-ra különböző további vizsgálatokban $[11,12]$.

\section{Célkitüzés}

Vizsgálatunk célja volt az epilepsziasebészet-hatékonyság rövid ( 1 és 2 év) és hosszú (5 év) távú változásának vizsgálata tízéves időszak alatt Intézetünkben. Összehasonlítottuk a korai (2006-2010) és a késői (2011-2016) intervallum beteganyagát és azt, hogy a technikai fejlődés hogyan befolyásolta a mútéti kimenetelt.

\section{Módszerek}

Az Országos Klinikai Idegtudományi Intézet klinikai adatbázisa alapján 2006 és 2016 között operált betegek adatai kerültek retrospektív feldolgozásra. A betegadatok felhasználása a helyi etikai bizottság előírása szerint anonim módon történt, és a vizsgálatot a helyi etikai bizottság hagyta jóvá (IKEB: 15/2019). A vizsgálatba olyan farmakorezisztens, fokális epilepsziás betegeket vontunk be, akiknél részletes mütéti kivizsgálás történt: skalpvagy invazív elektródával kiegészített video-EEG-monitorizálás, képalkotó (MRI, PET) és neuropszichológiai vizsgálat. Az MRI- és a skalp-video-EEG-felvétel beválogatási kritériumnak számított, míg a többi modalitás opcionális volt. A vizsgálatból kizártuk azokat a betegeket, akiknél reszektív beavatkozás nem történt: biopszia, csak elektródaimplantáció vagy neuromoduláció. Két, új típusú MRI-készülék volt elérhető, melyekkel a felvételek készültek a második periódusban: MAGNETOM Verio 3T (Siemens, München, Németország) és Ingenia 3.0T (Philips, Amszterdam, Hollandia). Epilepszia-MRI-protokoll: sagittalis síkú 3D GRE T1-, axiális síkú T2-súlyozott, valamint koronális síkú FLAIR-mérések készültek a koponyáról, majd $5 \mathrm{~mm}$-es vékony szeletes, koronális síkú T2-súlyozott mérések a temporalis lebenyek síkjára merőlegesen döntött helyzetben. Többéjszakás folyamatos video-EEG-monitorizálás történt standard 10/20-as és alsó temporalis lánccal $(\mathrm{F} 9 / 10, \mathrm{~T} 9 / 10, \mathrm{P9} / 10)$ kiegészített skalpelektródokkal. Invazív monitorizálás esetén subduralis, mély vagy foramen ovale elektródokat alkalmaztunk.

Vizsgálatunkban a következő információkat gyűjtöttük össze: demográfiai adatok, mútét előtti rohamfrekvencia, rohamindító zóna (klinikai megítélés MRI- és EEG-adatok alapján), az epilepszia kezdete, rohamszemiológia, az operáció típusa, hisztológiai lelet, mútét utáni rohamfrekvencia az 1 ., a 2. és az 5 . évben és posztoperatív szövődmények. A szövettani leletek alapján a következő kategóriák voltak felállíthatók: hippocampalis sclerosis (HS), fokális corticalis dysplasia (FCD), tumorok (beleértve az alacsony és magas malignitású tumorokat), vascularis malformatio (beleértve a cavernomákat és az angiovenosus fistulákat), kettős patológia (mint pél- dául alacsony malignitású glioma és HS vagy FCD együttes jelenléte). További leletek: gliosis, cysta, cysticus leukomalacia, contusio és ismeretlen eredetű eltérés. A lebenyi besorolásokat a mútét helye szerinti lokalizációban adtuk meg. Összehasonlítottuk a mütét előtti és utáni rohamfrekvenciákat, s ennek alapján megadtuk a módosított Engel-klasszifikációt [14] (Engel I/A: rohammentes; Engel I/B: néhány, korai tudatvesztéssel nem járó roham; Engel I/C: csak a mûtét után néhány, tudatvesztéssel járó roham; Engel I/D: csak gyógyszermegvonáskor jelentkező rohamok; Engel II/A: tudatvesztéssel járó, ritkán megjelenő rohamok; Engel II/B: tudatvesztéssel járó rohamok gyakrabban megjelenhetnek rögtön a mútétet követően; Engel II/C: ritkánál több, tudatvesztéssel járó roham; II/D: éjszakai rohamok; Engel III/A: érdemleges javulás; Engel III/B: rohamszámcsökkenés hosszabb időtartamban; Engel IV/A: nincs érdemleges javulás, talán kevés csökkenés; IV/B: egyáltalán nincs javulás; IV/C: sőt rosszabbodás is előfordulhat). A betegek mútét utáni követése során rövid (1. és 2. év) és hosszú (5. év) távú kimeneteleket határoztunk meg. A mütétet sikeresnek tekintettük, ha teljes rohammentességet sikerült elérni (Engel I/A) [15]. Az adatokat további két periódusra osztottuk, első (2006 és 2010 közötti) és második (2011 és 2016 közötti) intervallumra, melyeket külön-külön és összehasonlítva is elemeztünk. Adatainkat egytizedes pontosságig kerekítettük. A statisztikai összehasonlítást Fisher-féle egzakt khinégyzet-teszttel végeztük.

\section{Eredmények}

Beválogatási kritériumainknak 137 beteg felelt meg az operált 187, gyógyszerrezisztens fokális epilepsziás beteg közül. 54 beteget az első és 83 beteget a második periódusban operáltak. A demográfiai adatokat az 1. táblázatban összegeztük. A betegek 12,4\%-a volt 18 év alatti a mütétkor. 81 betegnél noninvazív preoperatív kivizsgálásra került sor (csak skalp-video-EEG), 42\% (n = 34) az első és $58 \%(\mathrm{n}=47)$ a második intervallumban került mütétre. 56 betegnél invazív kivizsgálás is történt (implantált elektródákkal), 35\% $(\mathrm{n}=20)$ az első és $65 \%$ $(\mathrm{n}=36)$ a második periódusban került mütétre.

1. táblázat | Demográfiai adatok a két periódusban

\begin{tabular}{lcc}
\hline & $\begin{array}{c}\text { Első } \\
\text { periódus } \\
(2006-2010)\end{array}$ & $\begin{array}{c}\text { Második } \\
\text { periódus } \\
(2011-2016)\end{array}$ \\
\hline A betegek száma & 54 & 83 \\
Nő & $44,40 \%$ & $48,20 \%$ \\
Férfi & $55,60 \%$ & $51,80 \%$ \\
Átlagéletkor a mütét időpontjában & 33,5 & 32 \\
Minimuméletkor & 8 & 9 \\
Maximuméletkor & 60 & 56 \\
\hline
\end{tabular}


2. táblázat | Sebészeti kimenetelek az Engel-klasszifikáció alapján

\begin{tabular}{|c|c|c|c|c|c|c|}
\hline & \multicolumn{2}{|c|}{ Kimenetelek az l. évben } & \multicolumn{2}{|c|}{ Kimenetelek a 2. évben } & \multicolumn{2}{|c|}{ Kimenetelek az 5. évben } \\
\hline & $\begin{array}{l}\text { A betegek száma } \\
\text { (n) }\end{array}$ & $\begin{array}{l}\text { Százalékos megoszlás (\%) } \\
\text { Összes beteg (132) }\end{array}$ & $\begin{array}{l}\text { A betegek száma } \\
\text { (n) }\end{array}$ & $\begin{array}{l}\text { Százalékos megoszlás (\%) } \\
\text { Összes beteg (128) }\end{array}$ & $\begin{array}{l}\text { A betegek száma } \\
(\mathrm{n})\end{array}$ & $\begin{array}{l}\text { Százalékos megoszlás (\%) } \\
\text { Összes beteg (104) }\end{array}$ \\
\hline $\mathrm{I} / \mathrm{A}$ & 90 & $68,1 \%$ & 82 & $64,1 \%$ & 65 & $62,5 \%$ \\
\hline $\mathrm{I} / \mathrm{B}$ & 10 & $7,6 \%$ & 7 & $5,4 \%$ & 4 & $3,9 \%$ \\
\hline $\mathrm{I} / \mathrm{C}$ & 1 & $0,8 \%$ & 0 & $0 \%$ & 2 & $1,9 \%$ \\
\hline $\mathrm{I} / \mathrm{D}$ & 2 & $1,5 \%$ & 2 & $1,6 \%$ & 1 & $0,9 \%$ \\
\hline II/A & 1 & $0,8 \%$ & 3 & $2,3 \%$ & 1 & $0,9 \%$ \\
\hline II/B & 10 & $7,6 \%$ & 6 & $4,7 \%$ & 3 & $2,9 \%$ \\
\hline $\mathrm{II} / \mathrm{C}$ & 0 & $0 \%$ & 1 & $0,8 \%$ & 1 & $0,9 \%$ \\
\hline $\mathrm{II} / \mathrm{D}$ & 0 & $0 \%$ & 0 & $0 \%$ & 0 & $0 \%$ \\
\hline III/A & 14 & $10,6 \%$ & 15 & $11,7 \%$ & 14 & $13,6 \%$ \\
\hline III/B & 0 & $0 \%$ & 1 & $0,8 \%$ & 1 & $0,9 \%$ \\
\hline IV. & 4 & $3 \%$ & 11 & $8,6 \%$ & 12 & $11,6 \%$ \\
\hline
\end{tabular}

Az összes 137 beteg mûtéti kimenetelét a 2. táblázat ábrázolja. A rövid távú rohammentességi arány (Engel $\mathrm{I} / \mathrm{A})$ az 1 . évben $68 \%$-ot $(\mathrm{n}=90)$, a 2 . évben $64 \%$-ot $(\mathrm{n}=82)$, míg a hosszú távú kimenetel az 5. évben 62,5\%ot $(\mathrm{n}=65)$ mutatott. A gyerekpopulációban hasonló rohammentességi arányokat mértünk: 67\% volt rohammentes az 1. és a 2. évben, majd $62,5 \%$ az 5 . évben. A kedvezőtlen kimenetelek aránya (változatlan vagy roszszabb rohamstatus; Engel IV.) az l. évben 3\%-ot $(\mathrm{n}=4)$ tett ki, ami 8,6\%-ra emelkedett a 2. évben és 11,6\%-ra $(\mathrm{n}=12)$ az 5 . évben.

A lebeny szerinti lokalizáció alapján a mútétek 65\%-a temporalis $(\mathrm{n}=89), 18 \%$-a frontalis $(\mathrm{n}=24), 10 \%$-a parietalis, insularis vagy occipitalis $(\mathrm{n}=14)$ és $7 \%$-a multilobaris $(\mathrm{n}=10)$ volt (ami a temporalis vagy a frontalis lebenyt érintette).

A szövettani vizsgálat alapján előfordult: FCD (30\%; $\mathrm{n}=41)$, HS $(18 \% ; \mathrm{n}=24)$, tumorok $(19 \% ; \mathrm{n}=26$ : diffúz astrocytoma: 3 ; pilocystás vagy egyéb, alacsony malignitású astrocytoma: 7; subependymalis óriássejtes astrocytoma: 1 ; ganglioglioma: 6 ; oligodendroglioma: 5 ; anaplasticus oligodendroglioma: 2 ; dysembryoplasticus neuroepithelialis tumor: 2 ), vascularis malformatio (14\%; $\mathrm{n}=19)$, kettős patológia $(8 \% ; \mathrm{n}=11)$ és egyéb etiológia $(11 \% ; n=16)$. A szövettani besorolás HS-nak minősült

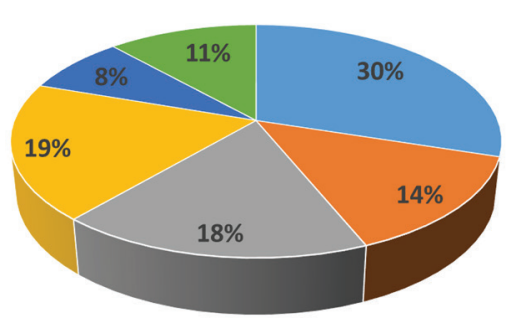

mCD

- Vascularis malformatio

-HS

-Tumor

Kettős patológia

-Egyéb etiológia

\begin{tabular}{l|l} 
1. ábra & $\begin{array}{l}\text { A hisztopatológiai leletek szerinti eloszlás } \\
\text { FCD = fokális corticalis dysplasia; HS = hippocampalis sclerosis }\end{array}$
\end{tabular} abban az esetben is, ha ezt csak az MRI erősítette meg egyértelmúen, de a hisztológia nem igazolta (1. ábra). A gyerekpopulációban az FCD magasabb arányban fordult elö, összességében 61\%-ban $(\mathrm{n}=8)$.

A hisztológiai és a radiológiai lelet közötti konkordancia változó volt: 80 betegnél $(58,4 \%)$ az MR- és a szövettani lelet megegyezett, míg 38 betegnél $(27,7 \%)$ eltérést találtunk. $19(13,9 \%)$ betegnek hiányzott a szövettani lelete. Az eltérést mutató betegek között 18 betegnek $(13,1 \%)$ nem egyezett az MR- és a szövettani eredménye (például az MR HS-t írt le, míg a szövettan FCD-t igazolt), 20 betegnél $(14,6 \%)$ pedig az MR bizonytalan HS-t, FCD-t vagy tumort véleményezett, majd a szövettani eredmény végül csak gliosist mutatott.

A kimeneteli eredményeket a lokalizáció és az etiológia alapján elemeztük (2. és 3. ábra). A rohammentességi arány temporalis epilepsziában $74 \%$, 66\% és $64 \%$ volt az 1., a 2., majd az 5. évben, míg frontalis reszekció esetén ez az arány 71\%-ra, 65\%-ra és 70\%-ra változott. A többi lebeny érintettségekor 46\%-os, 62\%-os és 50\%-os, míg multilobaris mútétek esetén $40 \%$-os, $50 \%$-os és $50 \%$-os megoszlás volt mérhető.

A legjobb kimeneteli eredményt 1 év után vascularis malformatio esetén lehetett elérni (89\%), ezt követette a HS (74\%), az FCD és tumorok (70\%), végül a kettős patológia (45\%) és az egyéb diagnózisok (44\%). Az eredmény hasonlóan alakult a 2 . és az 5 . évben: a legjobb a vascularis malformatio esetén volt, 95\% és 93\%, míg a tumoroknál 73\% és 65\%, az FCD esetén pedig 62\% és $61 \%$. A legnagyobb visszaesést HS-nél (59\% és 62\%) és kettős patológiánál (50\% és 33\%) detektáltuk.

A mütét időpontja alapján összehasonlítottuk a két intervallumot. A demográfiai adatokban nem volt szignifikáns különbség (1. táblázat), ugyanakkor azt találtuk, hogy az első periódusban a HS aránya magasabb, míg az FCD aránya alacsonyabb volt. Ez az eredmény nem érte el a statisztikai szignifikanciaszintet 


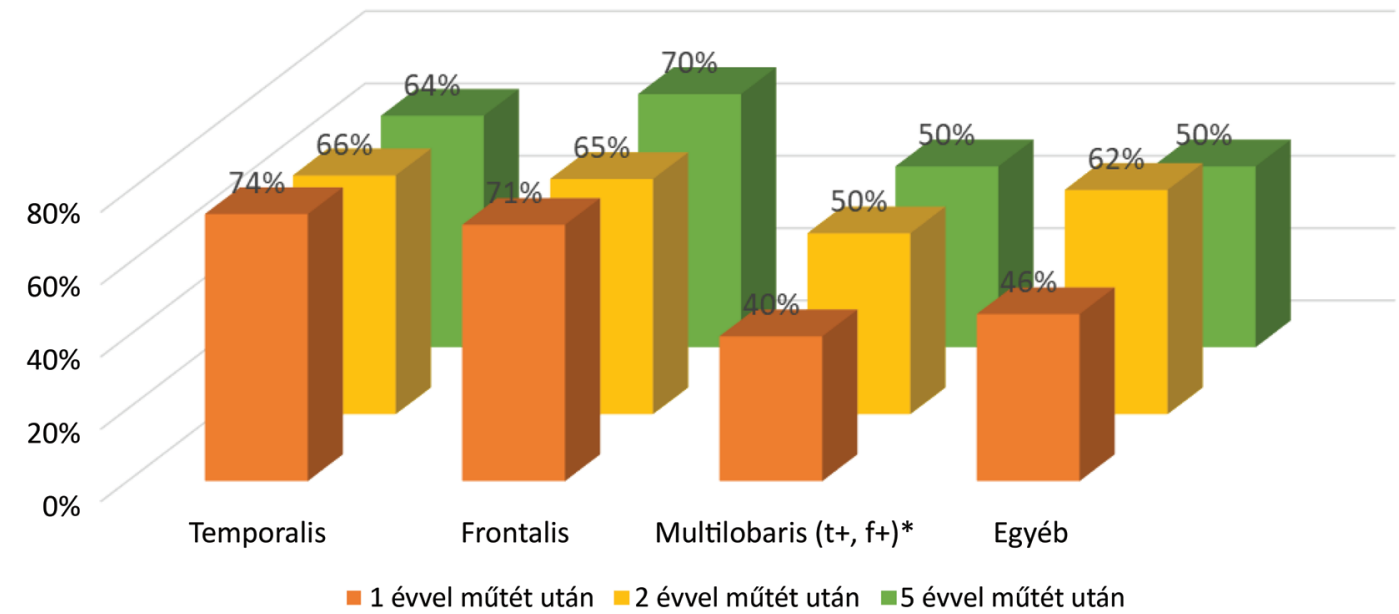

2. ábra

A rohammentesség eloszlása a lokalizáció függvényében

*Multilobaris mútét, mely a temporalis vagy a frontalis lebenyt érintette

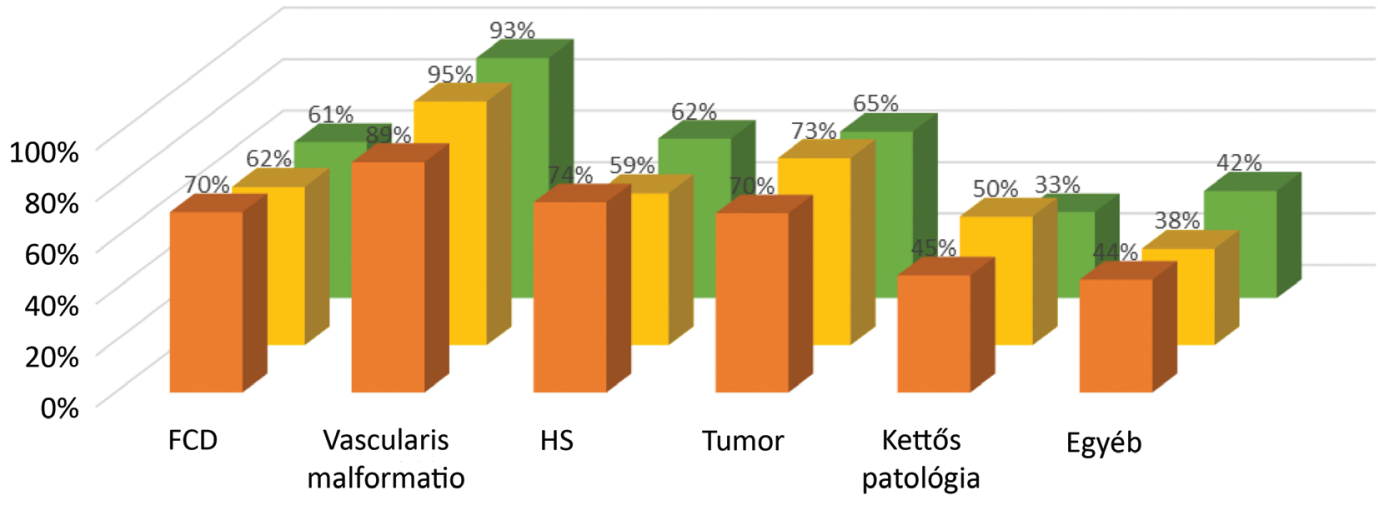

घ évvel műtét után $\square 2$ évvel mưtét után $\square 5$ évvel mútét után

\begin{tabular}{l|l} 
3. ábra & $\begin{array}{l}\text { A rohammentesség eloszlása az etiológia függvényében } \\
\text { FCD }=\text { fokális corticalis dysplasia; } H S=\text { hippocampalis sclerosis }\end{array}$
\end{tabular}

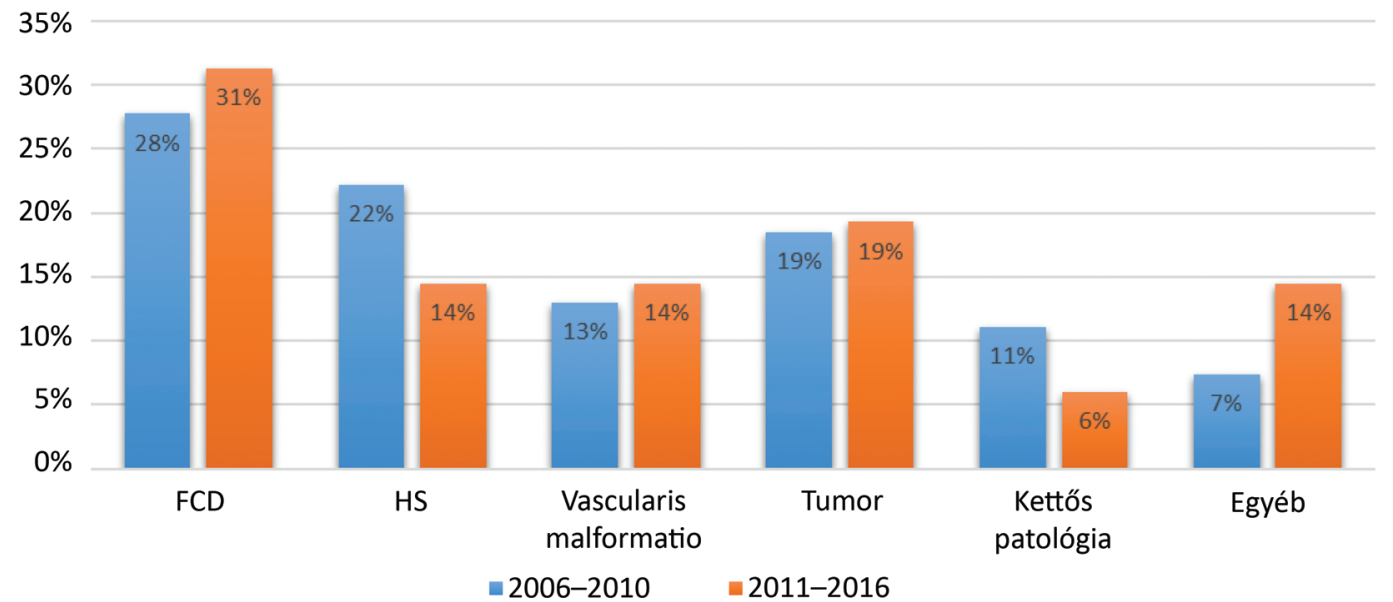

4. ábra

\begin{tabular}{|l} 
A hisztológiai leletek eloszlása a két periódusban \\
FCD = fokális corticalis dysplasia; HS = hippocampalis sclerosis
\end{tabular} 


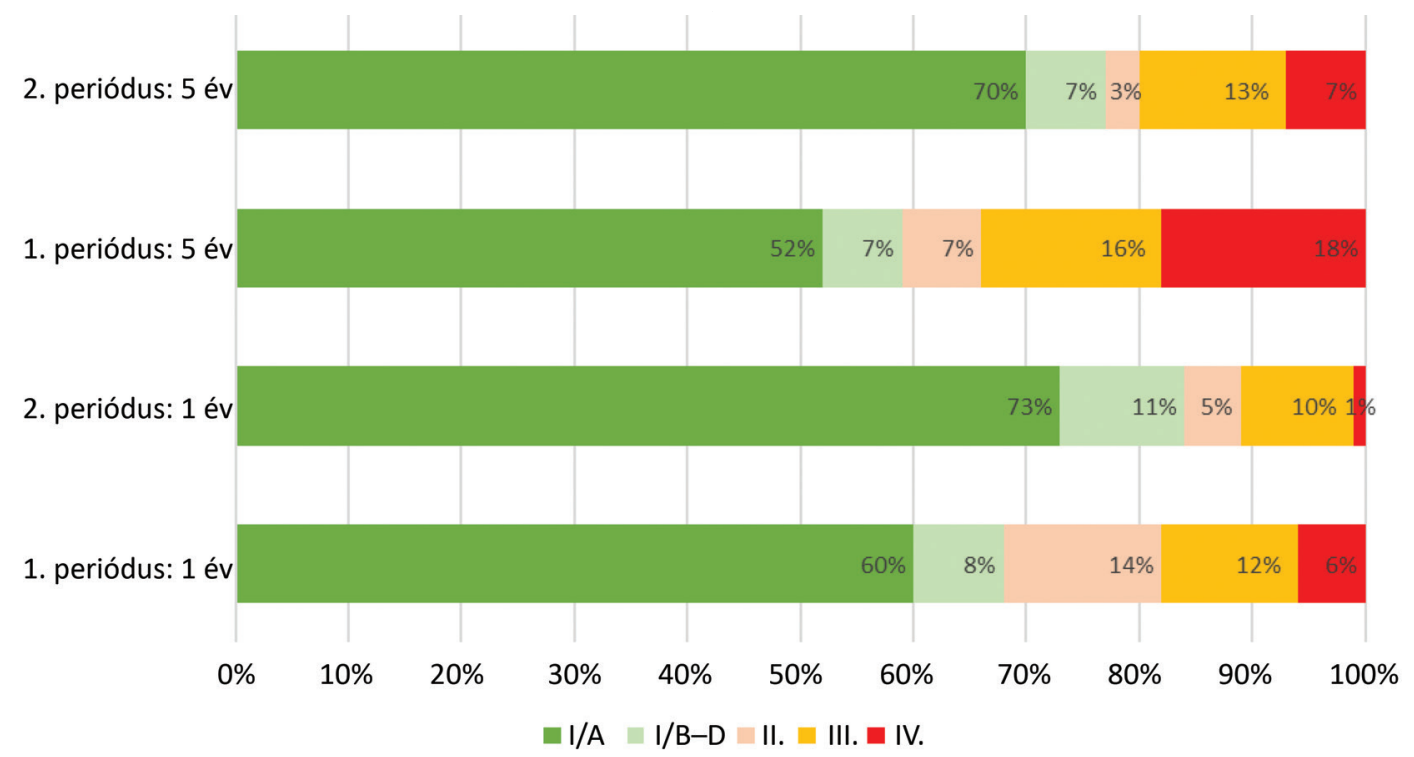

5. ábra

| A két periódus összehasonlítása

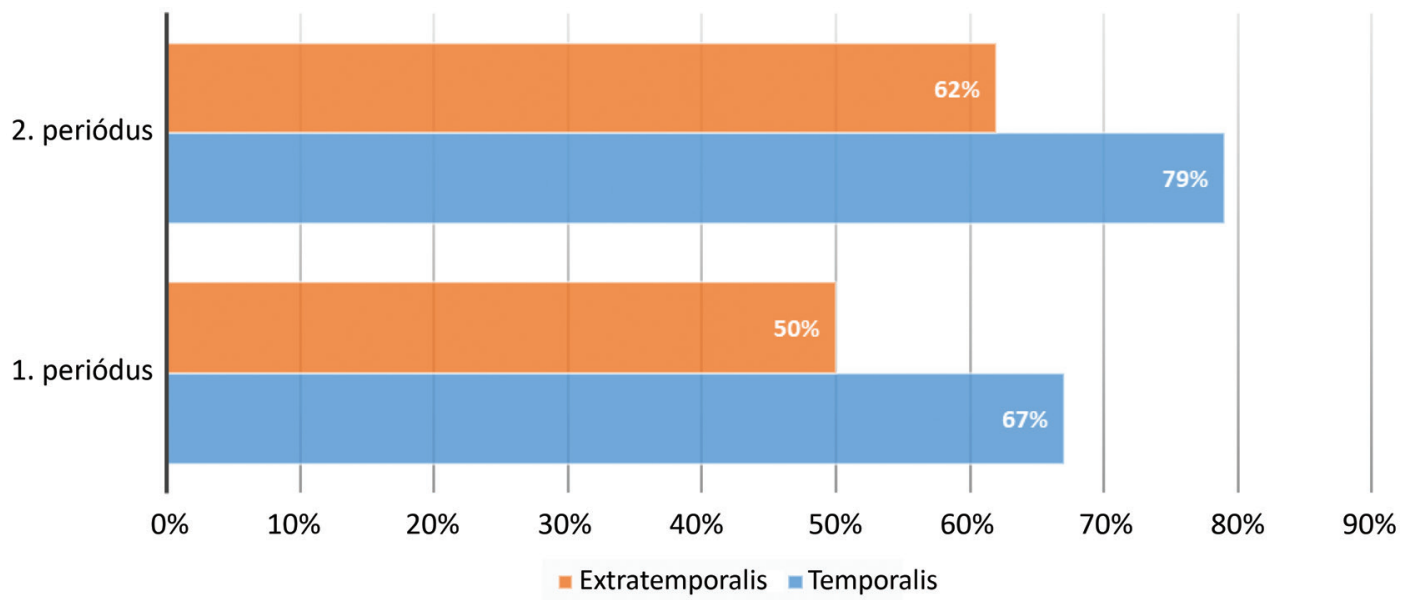

6. ábra

| A rohammentes betegek aránya (1 éves utánkövetés) a lokalizáció alapján a két periódusban

$\left(\mathrm{khi}^{2} \mathrm{p}=0,2 \mathrm{l}\right)$ (4. ábra). A második periódusban több MRI-negatív esetet találtunk: $7 \%(\mathrm{n}=6)$ kontra $4 \%$ $(\mathrm{n}=2)$. Az 1 éves rohammentességi arány az első periódusban $60 \%(\mathrm{n}=31)$, míg a második periódusban $73 \%$ $(\mathrm{n}=59)$ volt (statisztikailag nem szignifikáns: $\mathrm{khi}^{2} \mathrm{p}=$ 0,07 ) (5. ábra); a 2. évben hasonlóan alakult, $55 \%$ és 70 \% volt. A hosszú távú ( 5 éves) rohammentesség hasonlóan változott: $52 \%$ volt az első és 70\% a második időszakban. A kedvezőtlen kimenetelek ellentétes módon változtak: rövid távon az Engel III-IV. besorolás 18\%ban és 11\%-ban volt detektálható az első és a második időszakban, míg hosszú távon ugyanezen kategória 32\%-ban és 20\%-ban (5. ábra).

A mútét lokalizációja szerint felosztva az adatokat, a rohammentességi arány temporalisan $67 \%(\mathrm{n}=22)$, míg extratemporalisan $50 \%(\mathrm{n}=9)$ volt az elsó periódusban, mely temporalisan $79 \%$-ra $(n=42)$ és extratemporalisan 62\%-ra $(\mathrm{n}=18)$ javult a második időszakra (6. ábra).
Az életminőséget befolyásoló súlyos neurológiai szövődményt 9,5\%-ban ( $\mathrm{n}=13$ ) észleltünk, ezek közül hemiparesis 8,7\%-ban $(\mathrm{n}=12)$ volt. Ezen komplikációk magas kockázatú területek mütéteinél léptek fel: insula $(\mathrm{n}=3)$, supplementaer motoros area $(\mathrm{n}=1)$, a felső vagy a középső frontalis gyrus hátsó területei $(\mathrm{n}=4)$, posztcentrális gyrus $(\mathrm{n}=2$, hemihypaesthesiával kombinálva) vagy opercularis terület $(\mathrm{n}=2)$. Az életminőséget enyhén befolyásoló neurológiai szövődményt 8\%-ban ( $\mathrm{n}=11$ ) figyeltünk meg (a leggyakoribb a felső kvadráns anopia temporalis mútét után volt).

\section{Megbeszélés}

A TLE a leggyakoribb epilepsziatípus, és mútéti kimenetelei a legjobbak [16-18]. Eredményeink ennek megfelelőek: a betegek 65\%-ánál TLE-t igazoltunk, és ezen betegek 74\%-a rohammentes volt a mütét után 1 évvel. 
A leggyakoribb szövettani lelet a vizsgálati mintákban az FCD volt 30\%-kal, szemben az irodalmi adatokkal, amelyekben a HS-t jelölik meg a leggyakoribb leletnek [19]. A HS a mi vizsgálati anyagunkban 18\%-ban fordult elő. Az FCD növekvő előfordulását (2006-2010: 28\% és 2011-2016: 31\%) magyarázhatja az érzékenyebb MRI és a fejlettebb sebészeti teammunka, mely nehezebb sebészeti esetek számára is kivizsgálási lehetőséget nyújtott. Hasonló tendenciát, a HS csökkenő és az extratemporalis FCD növekvô előfordulását figyelték meg egy nagyobb, multicentrikus európai tanulmányban, melyben centrumunk is részt vett [20]. A legsikeresebben operálható etiológiának a vascularis malformatio tekinthető. A betegek 95\%-a rohammentessé vált 1 évvel a mütét után, és ez az arány évek múltán is hasonlóan alakult. A rövid távú rohammentesség nem különbözött HS-, FCD- és tumormútétek esetén (70\% körüli volt), ami hosszú távon is megőrződött, 60\% felett maradt. Ezzel szemben a kettős patológia és az egyéb etiológia sikerességi aránya rövid távon is $50 \%$ körül alakult, ami hosszú távon $50 \%$ alá csökkent. A legnagyobb csökkenést az 5 éves rohammentességi adatokban (több mint 10\%) HS és kettős patológia esetén észleltük. Ez jól mutatja, hogy HS esetén sokkal összetettebb etiológiáról beszélhetünk, mint várnánk, ezért alapos kivizsgálás válhat szükségessé még az egyszerünek tûnő esetekben is.

Összegezve az eredményeket, a rövid távú (1 éves) rohammentesség (Engel I/A) 68\%-ról 63\%-ra csökkent az 5. követési évben. Ugyanakkor a nagyon kedvezőtlen kimenetelek (változatlan vagy romló rohamfrekvencia: Engel IV.) rosszabbodtak az évek során: 1 évvel az operáció után 3\%-ra, 2 évvel utána 8,6\%-ra, míg 5 évvel a mütét után 11,6\%-ra emelkedett. Az 5. évben 12\%-os relapsust mértünk, amely kedvezőbb, mint más tanulmányok adatai [16]. A relapsus mögötti okok között szerepel az epilepsziás hálózat újjáépülése vagy a mütét során keletkezett hegszövet epileptogén transzformációja. Ezen tényezők pontosabb megítéléséhez további vizsgálatok és elemzések szükségesek. Nem vizsgáltuk a gyógyszerek változását az évek során, ami további zavaró tényező az adatok megítélésében.

A két vizsgált periódusban a betegek demográfiai adataiban nem volt különbség, de a második időszakban több kihívást jelentő sebészeti eset (MRI-negatív/FCD) került kivizsgálásra. Ennek ellenére mind a rövid, mind a hosszú távú kimenetelek jobbak lettek a második periódusban: 60\% kontra 73\% (1 éves utánkövetés), valamint $52 \%$ kontra $70 \%$ ( 5 éves utánkövetés); ugyanakkor a kedvezőtlen kimenetelek csökkentek: 20\% kontra 11\% (rövid távon) és 34\% kontra 20\% (hosszú távon). Ez az eredmény a mútét előtti kivizsgálási modalitások fejlődésével (a képalkotó technikák fejlődése, invazív EEG-monitorizálás), a tapasztaltabb teammunkával és a sebészeti technikák fejlődésével áll összefüggésben. A második periódusban nagyobb arányban (65\%) fordultak elő invazív monitorizálások.

\section{Következtetés}

Elmondhatjuk, hogy az epilepsziasebészet jó terápiás megoldás a gyógyszerrezisztens fokális epilepsziás betegek számára, és fejlődőképes. A mütét előtti kivizsgálás és a sebészeti technikák fejlődésével javulhattak a kimenetelek. A korábban inoperábilisnek tekintett betegeket be lehet vonni a sebészeti programba; a betegek szempontjából egyenlő mértékben érvényesül a neurológiai szövődmény miatti alacsony kockázat és a rohammentesség lehetősége nyújtotta előny. Meglátásunk szerint Magyarországon az epilepsziasebészeti mútétet továbbra sem használják ki teljes mértékben alternatív terápiaként. Ennek oka lehet a limitált kapacitás a mütét előtti kivizsgáláshoz, az invazív vizsgálatok megtérítésének hiánya, valamint a betegek és a neurológusok bizalmatlansága az epilepszia mütéti megoldásával szemben.

Anyagi támogatás: A cikk megírását a NAP2: 2017 1.2.1-NKP-2017-00002. számú (NKFIH-) pályázat támogatta.

Szerzői munkamegosztás: Közleményírás: J. Zs., Ho. B., F. D. A vizsgálat tervezése: E. L., H. P., F. D., F. A., K. A. A sebészeti beavatkozások elemzése és részleges végzése: E. L., H. L. Betegkövetés: K. A., F. D., H. P., F. A., U. Á., Ha. B., J. Zs. Adatelemzés: J. Zs., Ho. B., Ha. B. A cikk végleges változatát valamennyi szerző elolvasta és jóváhagyta.

Érdekeltségek: A szerzőknek nincsenek érdekeltségeik.

\section{Irodalom}

[1] Fiest KM, Sauro KM, Wiebe S, et al. Prevalence and incidence of epilepsy: a systematic review and meta-analysis of international studies. Neurology 2017; 88: 296-303.

[2] Neligan A, Bell GS, Shorvon SD, et al. Temporal trends in the mortality of people with epilepsy: a review. Epilepsia 2010; 51: 2241-2246.

[3] Shackleton DP, Westendorp RG, Trenité DG, et al. Mortality in patients with epilepsy: 40 years of follow up in a Dutch cohort study. J Neurol Neurosurg Psychiatry 1999; 66: 636-640.

[4] Thurman DJ, Logroscino G, Beghi E, et al. The burden of premature mortality of epilepsy in high-income countries: a systematic review from the Mortality Task Force of the International League Against Epilepsy. Epilepsia 2017; 58: 17-26.

[5] Kwan P, Brodie MJ. Early identification of refractory epilepsy. N Engl J Med. 2000; 342: 314-319.

[6] Kwan P, Arzimanoglou A, Berg AT, et al. Definition of drug resistant epilepsy: consensus proposal by the ad hoc Task Force of the ILAE Commission on Therapeutic Strategies. Epilepsia 2010; 51: 1069-1077.

[7] Jobst BC, Cascino GD. Resective epilepsy surgery for drugresistant focal epilepsy: a review. JAMA 2015; 313: 285-293.

[8] Poolos NP, Warner LN, Humphreys SZ, et al. Comparative efficacy of combination drug therapy in refractory epilepsy. Neurology 2012; 78: 62-68.

[9] Wiebe S, Blume WT, Girvin JP, et al. A randomized, controlled trial of surgery for temporal-lobe epilepsy. N Engl J Med. 2001; 345: 311-318. 
[10] Engel J Jr, McDermott MP, Wiebe S, et al. Early surgical therapy for drug-resistant temporal lobe epilepsy: a randomized trial. JAMA 2012; 307: 922-930.

[11] Noe K, Sulc V, Wong-Kisiel L, et al. Long-term outcomes after nonlesional extratemporal lobe epilepsy surgery. JAMA Neurol. 2013; 70: 1003-1008.

[12] Kim DW, Lee SK, Moon HJ, et al. Surgical treatment of nonlesional neocortical epilepsy. Long-term longitudinal study. JAMA Neurol. 2017; 74: 324-331.

[13] Lôrincz KN, Bóné B, Tóth M, et al. Postoperative outcome of surgical interventions for epilepsy between 2005 and 2016 at the Epilepsy Center of Pécs. [Epilepsziasebészeti beavatkozások eredményei a Pécsi Epilepszia Centrumban 2005 és 2016 között.] Orv Hetil. 2019; 160: 270-278. [Hungarian]

[14] Engel J Jr, Bernasconi A, Martinez V, et al. Outcome with respect to epileptic seizures. Surgical treatment of the epilepsies. $1993 ; 609-621$

[15] Malmgren K, Edelvik A. Long-term outcomes of surgical treatment for epilepsy in adults with regard to seizures, antiepileptic drug treatment and employment. Seizure 2017; 44: 217-224.
[16] de Tisi J, Bell GS, Peacock JL, et al. The long-term outcome of adult epilepsy surgery, patterns of seizure remission, and relapse: a cohort study. Lancet 2011; 378: 1388-1395.

[17] Hemb M, Palmini A, Paglioli E, et al. An 18-year follow-up of seizure outcome after surgery for temporal lobe epilepsy and hippocampal sclerosis. J Neurol Neurosurg Psychiatry 2013; 84: $800-805$

[18] Kelemen A, Barsi P, Erôss L, et al. Long-term outcome after temporal lobe surgery - prediction of late worsening of seizure control. Seizure 2006; 15: 49-55.

[19] Blumcke I, Spreafico R, Haaker G, et al. Histopathological findings in brain tissue obtained during epilepsy surgery. $\mathrm{N}$ Engl J Med. 2017; 377: 1648-1656.

[20] Baud MO, Perneger T, Rácz A, et al. European trends in epilepsy surgery. Neurology 2018; 91: e96-el06.

(Fabó Dániel dr., Budapest, Amerikai út 57., 1145 e-mail: fabo.daniel@gmail.com)

\section{Pályázati felhívás}

Dr. Fehér János professzornak, a Semmelweis Egyetem II. sz. Belgyógyászati Klinikája volt igazgatójának, az Orvosi Hetilap volt föszerkesztőjének emlékére 2011-ben alapítvány létesült.

A Dr. Fehér János Emlékére Alapítvány fö célja a belgyógyászat, különösen a hepatológia szabad gyökös és immunológiai vonatkozású témaköreinek kutatása, fejlesztése, támogatása, illetve ösztönzése oly módon, hogy az alapítvány kamatából fiatal egyetemi oktatók, PhD-hallgatók és orvostanhallgatók részesüljenek.

\section{A pályázatok benyújtásának határideje: 2021. április 15 .}

A dolgozatot „Dr. Fehér János pályázat” megjelöléssel kell benyújtani, és a pályázathoz mellékelni kell a pályázó önéletrajzát is.

A dolgozatot a Dr. Fehér János Emlékére Alapítvány Kuratóriuma elnökének

(Dr. Hagymási Krisztina) vagy titkárának (Dr. Lengyel Gabriella) kell eljuttatni.

Beküldési cím: Semmelweis Egyetem, I. Sebészeti és Intervenciós Gasztroenterológiai Klinika 1082 Budapest, Üllői út 78.

A díj odaítéléséről a kuratórium dönt. A díj átadására az Orvosi Hetilap Markusovszky-ünnepségén kerül sor, ahol a nyertes pályázó 5 perces előadásban foglalhatja össze az eredményeit. 